\title{
Disseminated herpes zoster infection in a splenectomized patient
}

\section{Zarif Tuce Ozkara Duman, Gulsen Akoglu}

\author{
Dermatovenereology Clinic, Ataturk Training and Research Hospital, Ankara, Turkey
}

Corresponding author: Dr. Gulsen Akoglu, E-mail: gusemd@yahoo.com

Sir,

Disseminated herpes zoster infection is usually observed in patients with HIV infection, malignancy, or during immunosuppressive treatments and is very rare in immunocompetent patients [1]. Herein, we report a patient with disseminated HZ after splenectomy due to trauma.

A 51-year-old male patient presented to our outpatient clinic with painful eruption on his face, neck, and trunk. He had type 2 diabetes mellitus and was on oral antidiabetic treatment. He had a splenectomy operation due to a trauma 18 years ago. Dermatological examination showed grouping papulovesicules and some crusts located on the $\mathrm{Vl}$ dermatome over right forehead and on the C3C4 dermatomes over left supraclavicular region. Leukocytosis (WBC: 13250/ml) and high C-reactive protein levels ( $19.4 \mathrm{mg} / \mathrm{dl}$; normal range: $0-5 \mathrm{mg} / \mathrm{dl}$ ) were detected in laboratory analyses. Liver and renal function tests and urinalysis were all within normal limits. Anti-HIV antibody was negative. He was diagnosed as having disseminated herpes zoster and put on acyclovir treatment with a dosage of $3 \times 10 \mathrm{mg} /$ $\mathrm{kg} / \mathrm{d}$ intravenously. In the follow up, impairment of renal function was detected on the third day of acyclovir therapy. Treatment was stopped due to acute renal failure caused by acyclovir and the patient was treated with intravenous hydration. After five days, renal functions improved markedly and skin lesions healed.

Varicella zoster virus (VZV) is a double-stranded DNA virus belonging to herpes virus family. The virus remains latent in sensory root ganglions after recovery from primary VZV infection, acute varicella or chickenpox. Intact VZV specific cellular immunity blocks the reactivation. Upon decline in cell mediated immunity caused by natural aging, trauma, stress, T cell defects, HIV infection, chemotherapy, or bone marrow transplantation, the virus reactivates and reaches to the related dermatomal skin region through the sensorial nerve axon, presenting as herpes zoster infection $[1,2]$. The involved dermatomes are usually adjacent and unilateral in immunocompetent patients and dissemination is very rare [1-3]. Development of 20 or more vesicular lesions of HZ extending outside the main involved dermatome is called disseminated HZ infection. Dissemination is extremely rare except for the patients with HIV infection, malignancy, and who are on immunosuppressive treatment [1]. Mazur and Dalin reviewed 107 cases of HZ during a 20 year period and reported cutaneous dissemination in $15 \%$ of patients, which most frequently occurred in splenectomized patients with Hodgkin's disease and in patients having systemic corticosteroid therapy [4]. Manning et al. reported only 3 patients with HZ, two of which were associated with generalized cutaneous dissemination, among 102 patients who had undergone splenectomy for non-malignant disease such as trauma, surgical complications, and hematologic indications. They suggest that splenectomy does not predispose to HZ; however, may involve in cutaneous dissemination [5].

Spleen is an important lymphoid tissue involved in both humoral and cellular immunity. Many immunological mechanisms such as $\mathrm{T}$ and $\mathrm{B}$ cell maturating processes,

DOI:10.7241/ourd.20184.27 
production of specific antibodies against circulating bacteria, and phagocytosis of cells opsonized with antibodies take place in the spleen. Therefore, spleen has an essential and important function in protecting the host from infections. Splenectomized patients have immunological defects including altered immunoglobulin levels, lower activation in alternative pathway of complement system, lack of opsonizing proteins in serum, and defective function of T helper cells [6]. We suggest that the defect in immune system depending on splenectomy caused reactivation of $V Z V$ infection and disseminated cutaneous HZ in our patient. In conclusion, herpes zoster may present as disseminated form in patients with splenectomy. Patients with diagnose of disseminated HZ infection should be questioned for history of splenectomy.

\section{Consent}

The examination of the patient was conducted according to the Declaration of Helsinki principles.

\section{REFERENCES}

1. Moquete RA, Hartman B, Granstein RD. Herpes zoster with cutaneous dissemination in a patient 21 years after splenectomy for idiopathic thrombocytopenic purpura. J Cutan Med Surg. 2012;16:368-71.

2. Takaoka Y, Miyachi Y, Yoshikawa Y, Tanioka M, Fujisawa A, Endo Y. Bilateral disseminated herpes zoster in an immunocompetent host. Dermatol Online J. 2013;19:13.

3. Brar BK, Gupta RR, Saghni SS. Bilateral herpes-Zoster of widely separated dermatomes in a non-immunocompromised female. Indian J Dermatol Venereol Leprol. 2002;68:48-9.

4. Mazur MH, Dolin R. Herpes zoster at the NIH: a 20 year experience. Am J Med.1978;65:738-44.

5. Manning DM, Luparello FJ, Arena VC Jr. Herpes zoster after splenectomy. A study of patients without malignancy. JAMA. 1980;243:56-8.

6. Vasilesca C. Chapter 2. Functions of the spleen and their evaluation. In: The Spleen. Ed. Petroianu A. Hilversum, The Netherlands: Bentham Science Publishers. 2011;20-36.

Copyright by Zarif Tuce Ozkara Duman, et al. This is an open-access article distributed under the terms of the Creative Commons Attribution License, which permits unrestricted use, distribution, and reproduction in any medium, provided the original author and source are credited.

Source of Support: Nil, Conflict of Interest: None declared. 